\title{
Environmental impacts of subsidence around the Barapukuria Coal Mining area in Bangladesh
}

\author{
M. Farhad Howladar ${ }^{1}$ \\ ${ }^{1}$ Department of Petroleum and Mining Engineering, Shahjalal University of Science and Technology, Sylhet 3114, Bangladesh
}

Received: 10 January 2016/Revised: 22 May 2016/Accepted: 30 May 2016/Published online: 21 June 2016

(C) Joint Center on Global Change and Earth System Science of the University of Maryland and Beijing Normal University and Springer-Verlag Berlin Heidelberg 2016

\begin{abstract}
Underground coal mining-induced land subsidence has large impacts on different components of natural environment such as changing the morphology of land settlements and soil characteristics, interrupting the hydrologic environment, damaging different structures, disordering the chain of social environment and so on. In view of these consequences, primarily this research recognized and estimated subsidence in field which compared with empirically predicted maximum depth and type of subsidence in the area. Secondly, the current situations of various environmental components were studied under intensive field investigations. From the field, it has observed that more than one square kilometer land settlements subsided with a depth at the center of subsidence is about $1 \mathrm{~m}$. In fact, the depth of subsidence decreased gradually toward the virgin area, hence formed a trough shape structure which is more or less matched with the empirically predicted trough subsidence around the mine. The present noticeable impact of subsidence on different structures such as mud wall, brick wall of house, road, yard, land and others are deformed very slight to slight, and very few cases are severe. In the case of water environment, this study recognized that the whole trough area appeared as a big nonnatural lake/water reservoir where the water quality analysis revealed that major cations and anions excluding $\mathrm{pH}$ values are slightly below the standard limit suggested the degradation of water quality; then, water level data analysis reflected that the water level lowered considerably with respect to its previous state. These scenarios also directly or indirectly supported by the
\end{abstract}

M. Farhad Howladar

farhadpme@gmail.com; farhad-pme@sust.edu soil permeability analysis even as the permeable properties of soil reduced than the virgin area which might be interrupted the natural water recharge condition as a result depleted the groundwater level. Moreover, from the community consultations around the mines, it is realized that the impact of subsidence on social environment is noticeable and tormenting for future. In conclusion, the research provides recommendations for planning and management of subsidence and safe environment which ultimately be helpful for sound production of coal from the mine for present and future.

Keywords Barapukuria Coal Mine · Subsidence · Environments $\cdot$ Subsidence management

\section{Introduction}

The underground coal mining operations and land subsidence are very frequent and interrelated events around the mining area in the world. It is well known that coal itself a less competent rock as well as its overlying strata. In the case of Barapukuria Coal Mine, the characteristics of coal are highly volatile and bituminous where this coal-bearing formation stratigraphically exist below the Dupi Tila water-bearing formation (Wardell 1991), naturally vulnerable to have subsidence incident in the area. The type, intensity and related environmental impacts of mine subsidence usually depend on the applied mining method, size of the operation, depth and dip of the coal seam, existed geologic discontinuities and subsidence control plan. The impacts of subsidence on structures and environment have examined by Skempton and MacDonald (1956), Polshin 
and Tokar (1957), Burland and Wroth (1975), Howladar (2012), Howladar et al. (2014), Howladar and Karim (2014). However, subsidence has always been a consequence of underground mining (Steve et al. 2002; Agricola 1950; Gregory 1982; Kratzsch 1983; Whittaker and Reddish 1989; Singh 1992; Chang et al. 2004; Quamruzzaman et al. 2009; Howladar and Hasan 2014). Moreover, the environmental impacts caused by coal mining subsidence become increasingly serious, threatening the ecological safety in the mining areas (Shi et al. 2010). Consequently, the environmental pollutions by subsidence create a significant communal problem (König et al. 2010; Bickerstaff and Walker 2001). The usual environmental concerns in the mining areas mainly focus on the technical aspects such as clean coal technology, comprehensive utilization of coal gangues, land reclamation and the like (König et al. 2010; Dong and Liu 2005). In the case of the present study area, the geological, hydrological, geostructural, geotechnical, geophysical, coal quality, mining method and environment-related research have already been carried out by different researchers such Alam (1972), Zaher and Rahman (1980), Bakr et al. (1996), Wardell (1991), Khan and Rahman (1992), CMC (1999), Imam (2005), EIA (2006), Islam and Hayashi (2008), Muller (2009), Howladar (2012), Hashan et al. (2013), Karim and Howladar (2013), Karim et al. (2014), Howladar and Hasan (2014), Howladar and Karim (2014), and Howladar et al. (2015). Unluckily, the integrated research on the mining subsidence and environment is still missing even if the subsidence-induced environmental threats create a critical barrier to sustainable coal extraction from this mine as well as the development of other coal mine field in Bangladesh. For these reasons, the mining subsidence and its impacts on different components of environment are much needed to be carefully examined and monitored in the area. Thus, this study mainly focuses on the mine subsidence and the contemporary state of various component of environment by conducting primarily the type of subsidence, maximum depth of subsidence at the center, total subsided area, soil permeability, surface water quality, state of underground water level, land settlement and the condition of different physical structures in the area through direct field investigations, and laboratory analysis; secondly, the community consultation has been performed to collect necessary data to show the overall environmental status around the area. Finally, the nature of subsidence with its associated impacts on environment around the Barapukuria Underground coal mine has been discussed and provided the necessary recommendations for minimizing the subsidence for future safely production of coal, environmental improvement, planning and policy-making around the mine area.

\section{Geographic setting, geologic characteristics and coal field development history of the mine area}

\subsection{Geographic setting of the mine area}

Barapukuria Coal Mining Company Limited (Fig. 1) lies between the latitudes $23^{\circ} 31^{\prime} 45^{\prime \prime}$ and $23^{\circ} 33^{\prime} 05^{\prime \prime} \mathrm{N}$ and the longitudes $88^{\circ} 57^{\prime} 48^{\prime \prime}$ and $88^{\circ} 58^{\prime} 53^{\prime \prime} \mathrm{E}$. This coal field stretches $4.9 \mathrm{~km}$ northeast, with proved area of approximately $5.8 \mathrm{~km}^{2}$, and has an unproved possible extension area to the south approximately $1-1.5 \mathrm{~km}^{2}$ (Wardell 1991). Geomorphologically, the area is a part of alluvial plain of rivers Ghirnai and Khorkhori, and occupied by Barind Tract, Old Himalayan flood plain and Tista flood plain (SRDI 1999). The population density of the study area is about 685 people per sq. $\mathrm{km}$. Climate of the study area slouches in the north of the "Tropical of Cancer" exhibiting a subtropical pattern characterized by relatively arid cool winter, and hot and humid sweltering summer with substantial amount of monsoon rainfall (CMC 1994; Uddin 2003).

\subsection{Geologic characteristics of the mine area}

Geologically (Fig. 2), the entire territory of Bangladesh is occupied by the Bengal Basin (Bakr et al. 1996). Bangladesh largely covers two major tectonic elements: (a) Indian Platform (Shelf area) - a stable shelf with reduced thickness of sediment; and (b) Bengal Foredeep (geosynclinal area) - a deeper part of the basin with rapid increase in thickness of individual formation (Khan and Agarwal 1993). The geologic structure (Fig. 2) and stratigraphy of the Barapukuria coal basin have been delineated with the help of borehole data and seismic survey by the Geological Survey of Bangladesh and the Wardell Armstrong. The study area consists of a half-faulted graben-controlled sedimentary basin of Permo-Carboniferous age. The lower most Permo-Carboniferous glacial and fluvioglacial sediments resting unconformable on an ancient denuded Archean basement complex. Above this zone, thick predominantly continental arenaceous sediments with a number of coal seams of Permian age are present. This basin is concealed by an unconformable cover of about 100-200 m of Tertiary sediments known as the Dupi Tila Formation, which is supposed to be of Pliocene age (Bakr et al. 1996). Based on the core analyses and drill hole data, the sedimentary succession of the basin has been divided from bottom upward into three units such as Gondwana Group, Dupi Tila Formation and Modhupur Clay Formation (Uddin and Islam 1992; CMC 1999). The coal-bearing Gondwana Group of sediment is Permian in age and rests 
Fig. 1 Location map of the study area (modified after Imam 2005; Howladar and Islam 2016)

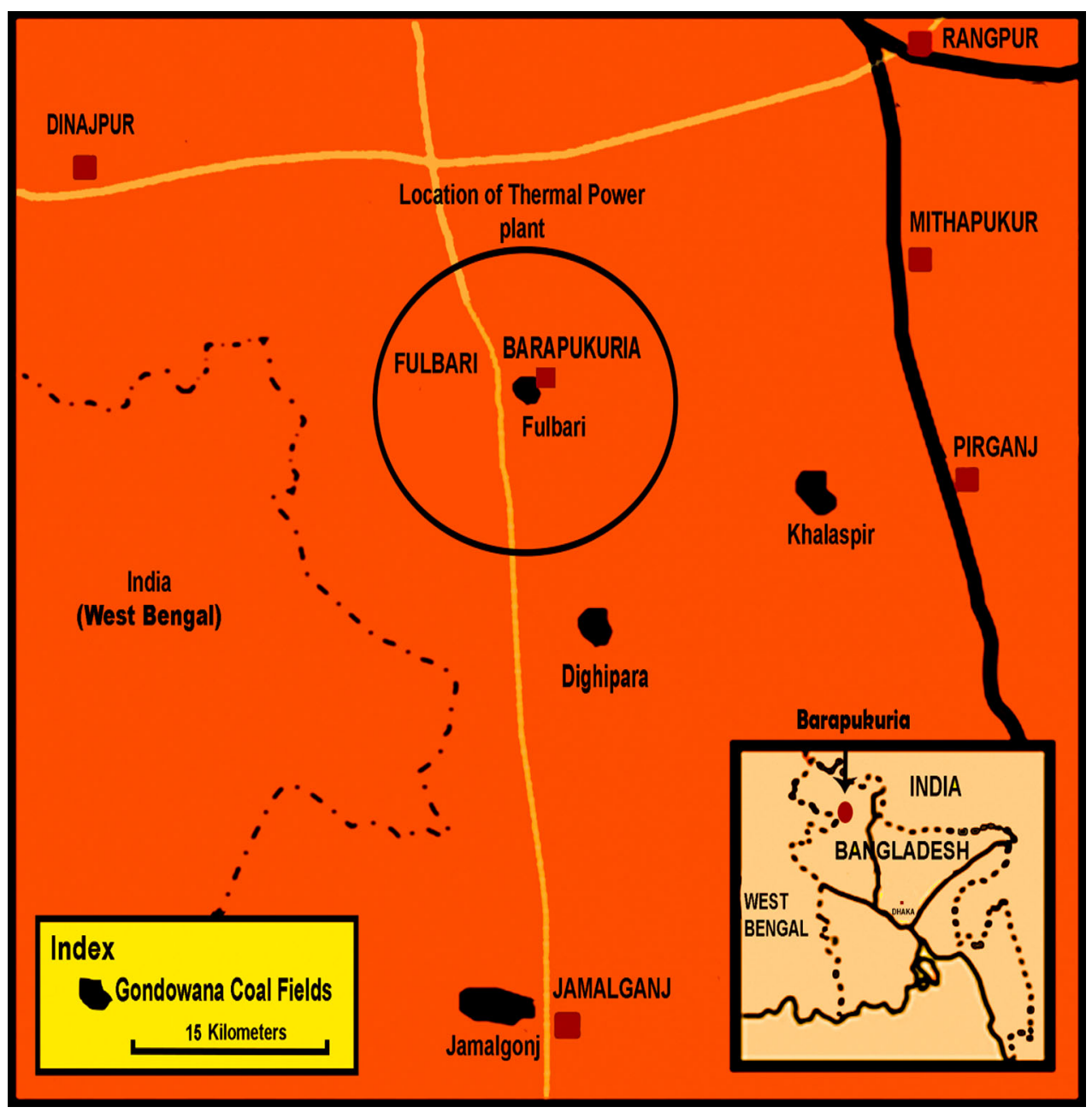

unconformably on Precambrian crystalline igneous and metamorphic basement. The Gondwana Group is predominantly composed of hard sandstone with some shale, conglomerate and coal beds (Khan and Rahman 1992). Dupi Tila Formation is composed of unconsolidated to poorly consolidated, medium- to coarse-grained occasionally pebbly sands with some minor clay beds. It is Pliocene in age and lies above the Permian Gondwana Group with major unconformity. The poorly consolidated Dupi Tila sand unit is a freshwater-bearing aquifer, and it may pose problem for mining of the coal. The Modhupur Clay unit in Barapukuria coal field area is characterized by $3-15 \mathrm{~m}$ thick silty clay unconformably overlaying the Dupi Tila Formation (Imam 2005).

\subsection{History of coal field development plan}

Barapukuria Coal Mining field is the first developed coal mine in Bangladesh which primary discovering and developing works were started in the mid of last century. In 1950, Standard Vacuum Oil Company carried out seismic reflection survey in the northwestern part of Bangladesh, then 1963 Oil and Gas Development Company performed another seismic survey in this region (CMC 1994). Consequently, the Geological Survey of Bangladesh (GSB) first confirmed the presence of $157 \mathrm{~m}$ thick Gondwana sediment between the Basement and Tertiary sediments in Barapukuria area in 1987 by a detailed geophysical survey and borehole drilling at the region. This investigation also noted that the coalfield contains 7 coal-bearing seams with total thickness of $74.14 \mathrm{~m}$ where the Seam VI is the main mineable bed of which thickness ranging from 29.4 to $41 \mathrm{~m}$. Then, the feasibility study for the development of Barapukuria Coal Mine has been conducted by Wardell Armstrong a British consulting firm in 1991 (CMC 1994, 1999). Based on all technical, geological, hydrological and feasibility study reports, the coal minefield has been divided into two mining districts, as No. 1 (Southern) mining district and No. 2 (Northern) district. The current development works run through the No. 1 (southern) mining district by longwall face slicing method. The northern district will be excavated later by adopting room and pillar 


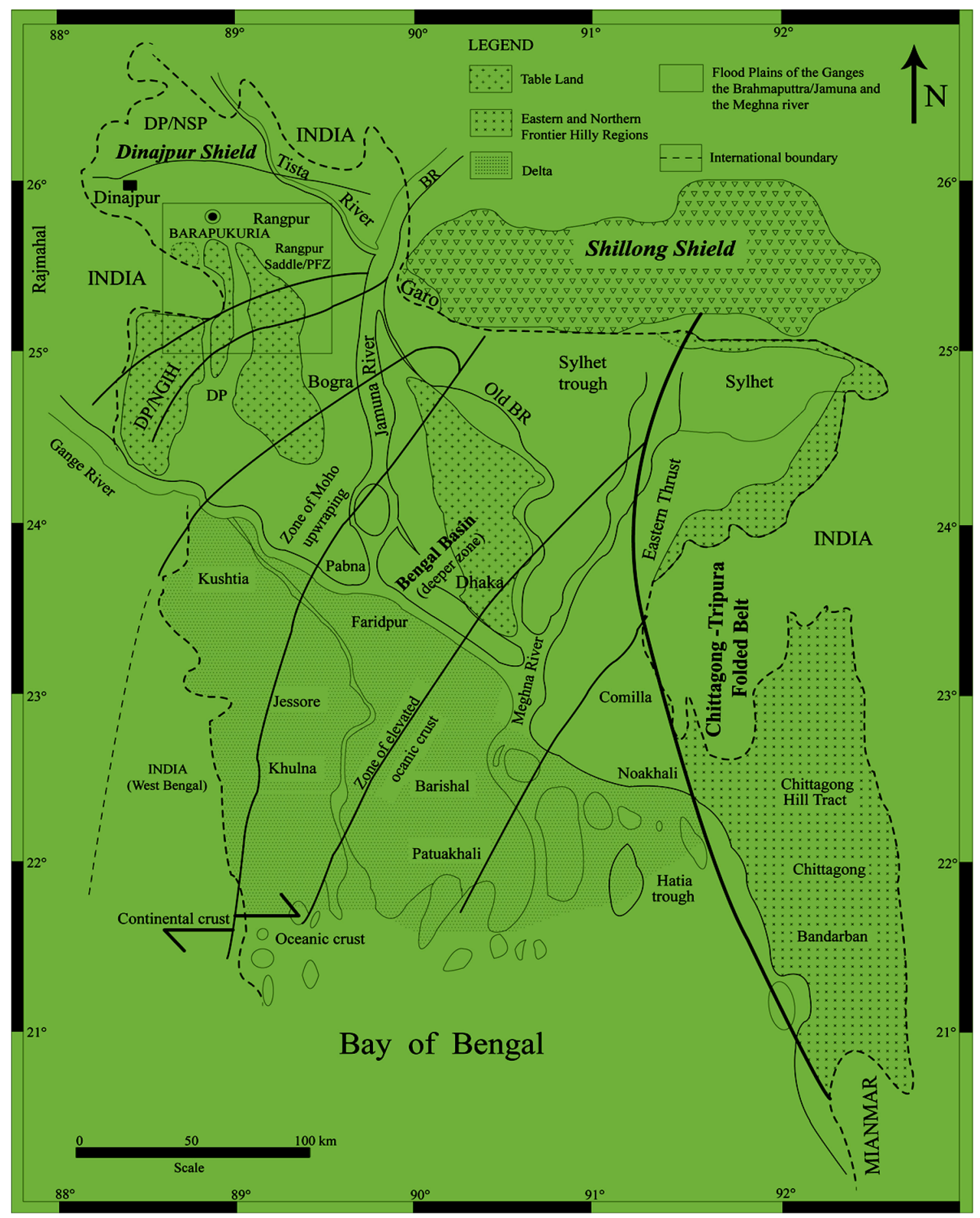

Fig. 2 Geologic and tectonic setting of the Barapukuria Coal Mine Basin, Dinajpur, Bangladesh, where $B R$ Brahmaputra River, DP Dinajpur Platform, NGIH Nawabganj-Gaibandha intracratonic high,

mining method. However, a representative basic design and developing plan of the Barapukuria coal mining project at a glance is shown in Fig. 3. Consequently, the Barapukuria Coal Mine was commenced its construction works
NSP north slope of the platform, $P F Z$ platform flank zone (modified after Khan 1991; Khan and Chouhan 1996; Islam et al. 2009; Howladar et al. 2014)

in June, 1996 and the commercial coal production was started in September 2005 (Islam and Hayashi 2008; Howladar 2012) under the Jiangsu Coal Geology Company. 
Fig. 3 Development plan of coal extraction (plan view for levels -260 to $-420 \mathrm{~m}$ ) of the Barapukuria Coal Mining Company (CMC 1993; Islam et al. 2009)

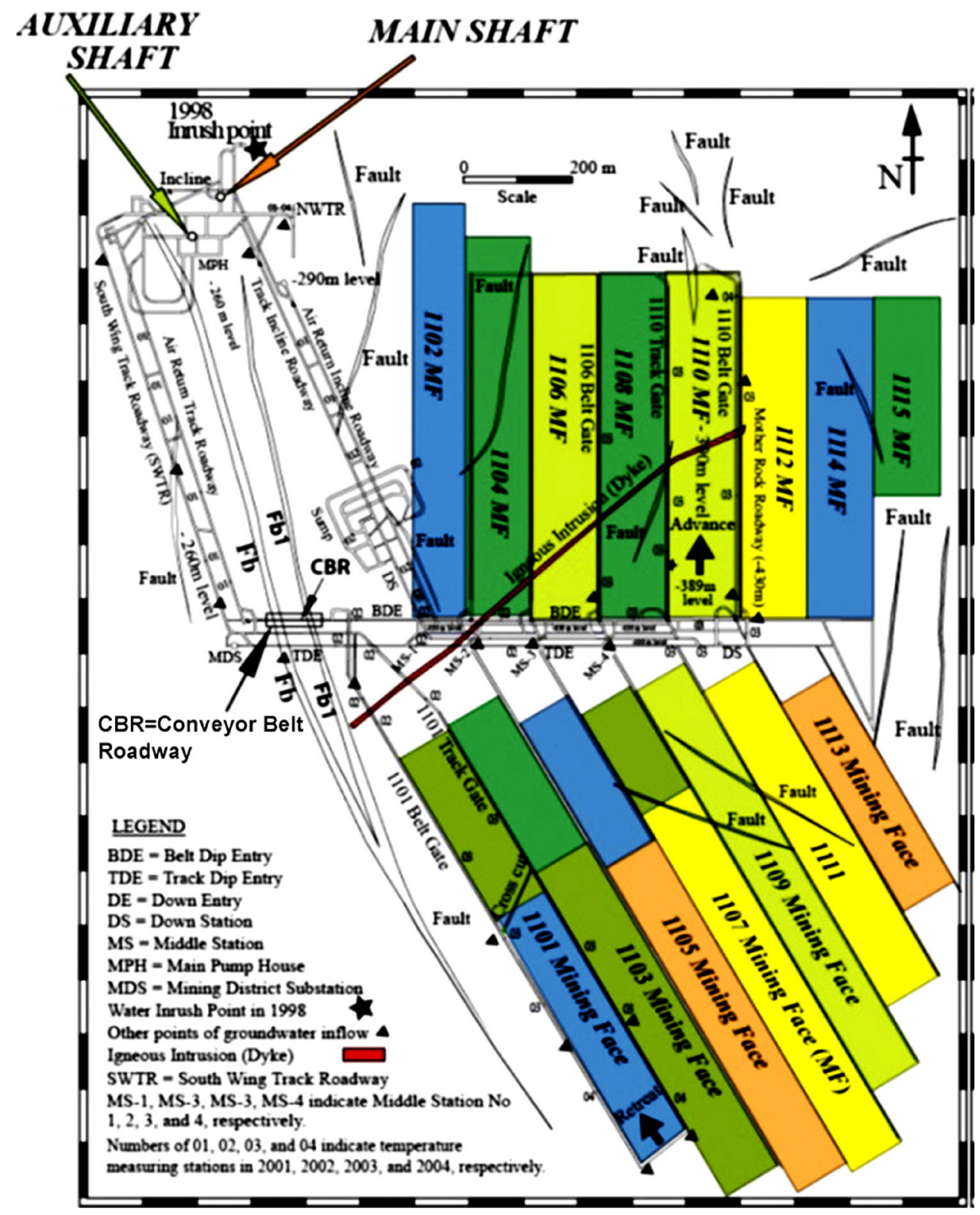

\subsection{Necessities of the extraction of coal resources in Bangladesh}

The coal itself a valuable georesources that is widely used in the power sectors to generate electricity in the world. However, the power sectors in Bangladesh are still thoroughly depending on the natural gas which reserves are not sufficient with respect to our present as well as future demand. Under this reality, we should consider regarding the extraction and exploitation of coal, while there are about two billion tons of coal reserves in five coal fields which are more than three to four times the known gas reserves in Bangladesh. Among these five fields, Barapukuria coal field is only developed mine in Bangladesh which is currently under production state with a target production capacity of 1 million metric ton per annum. Targeting this production of coal from this mine, a number of industries such as $250 \mathrm{MW}$ electric power plant, brick manufacturing plant and so many have already been established which would use this coal as the sole energy sources. In the event of any production failure of the coal mine, these industries would inevitably face a bleak future which eventually would in turn hurt the national economy. Moreover, s safe, reliable and adequate supply of the electricity is prerequisite needs for the development of any country for maintaining its economic activities, i.e., business, farms, factories, industries and hospitals. However, a matter of great regrets that Bangladesh is fighting hard in 
facing the domestic need of electricity till date. Electricity crisis is menacing and one of the crucial issues of Bangladesh. To meet this demand, the extraction of coal resources is very much essential in Bangladesh.

\section{Materials and methods}

Several field investigations have been carried out around the mining area to recognize the subsidence and the affected different environmental parameters such as overall land settlement, different structures, soil permeability, water logging position, quality of water, condition of water level, public reactions and others. The relevant photographs and evidences collected from field have been shown in the respective subsections of this research. In the case of subsidence recognition in field, the total subsided areas have been divided into several subdivisions which are NS, EW, NE-SW and NW-SE then following these directions; the depths of subsidence in different positions have been estimated. Finally, the field recognized features compared with the maximum depth at the center and type of subsidence predicted by numerical and empirical methods by Mamun (2011) and Howladar and Hasan (2014), respectively.

\subsection{Soil quality and permeability analysis}

In order to assess the surface soil permeability, ten soil samples (five samples from subsided area and five from virgin area) have been collected in different time from the fields which have been analyzed in the laboratory and the coefficient of permeability of the sample calculated using the equation, i.e.,

$K_{T}=Q L / A_{t} h$

where $K_{T}$ coefficient of permeability $(\mathrm{cm} / \mathrm{s}), L$ length of the specimen $(\mathrm{cm}), Q$ volume rate of flow through the fill $\left(\mathrm{m}^{3} / \mathrm{s}\right), A$ cross-sectional area of the fill $\left(\mathrm{m}^{2}\right)$ and $h$ head differential across the fill (m).

Finally, the results of these analyses have been shown in Table 1.

\subsection{Hydrological data analysis}

To realize the hydrological condition, the two principal types of analysis such as surface water samples and water level for some selective wells have been accomplished around the area. However, the primary water level data for different wells collected from the Barapukuria Coal Mine authority and their modified form for different wells from 2001 to 2011 were taken from Howladar (2012) research shown in as a representative Table 2. Then, ten water samples were collected from different locations of the subsided water logged area by the end of October 2013 and stored them in polyethylene bottles. All bottles washed well had been rinsed with deionized water before sampling. Immediately after sampling, $\mathrm{pH}, \mathrm{EC}$, TDS and temperature were measured in the field by a portable $\mathrm{pH}$ (Hanna) and an EC/TDS meter (Hanna). The other parameters of the samples analyzed in the laboratory which results shown in Table 3.

\subsection{Questionnaires survey in the community}

The community consultations have been conducted in June-August 2014 to understand the positive or negative impact of subsidence and mining operations on the overall socioeconomic and environmental development or degradation in the area. During this process, firstly the random respondents have been selected from different places around the mine, considering their gender, age, educational level, occupation and proximity to mine; secondly, they have asked some selective questions on various things such as land, water, damaging or deforming any structures or plants, air, health, compensation against the damage, training or any awareness program on subsidence consequences, cooperation from mining authority, socioeconomic status, etc. Finally, their respective responses have been noted for further analysis and interpretation.

\section{Results and discussions}

\subsection{Investigated subsidence in field with its comparison}

Subsidence is an observable feature associated with different factors such as compaction of natural sediments, groundwater dewatering, extraction of petroleum and geothermal fluids, and mining of coal, limestone, salt, sulfur and metallic ores (Soliman 1998). The type and rate of subsidence that results from longwall mining depend upon the width of a longwall panel, the depth at which mining takes place, the height of the coal seam, the width of the panels and a variety of geotechnical factors (Bell et al. 2000). The type of subsidence is generally localized in extent, affecting a relatively small area on the overlying surface (Park 1987). In the case of Barapukuria Coal Mine, the fully mechanized multi-sliced longwall pillar-less mining method has been employed for extracting coal from mine and consequently the subsidence incidence occurred over the coal extracted areas. The longwall pillar-less mining method where seam is removed in one operation by means of a long working face or wall. The workings (face) are undercut by removing a slice causing it to cave under 
Table 1 Characteristics of surface soil permeability in the subsided and virgin area

\begin{tabular}{|c|c|c|c|c|c|}
\hline \multirow[t]{2}{*}{ Sample no. } & \multicolumn{2}{|l|}{ Location } & \multirow[t]{2}{*}{ Types of the samples } & \multirow[t]{2}{*}{ Applied method } & \multirow[t]{2}{*}{ Average $K_{T}(\mathrm{~cm} / \mathrm{s})$} \\
\hline & Longitude & Latitude & & & \\
\hline 1 & 25.54438 & 88.96468 & Subsided area & Constant head method & $1.0548 \times 10^{-6}$ \\
\hline 2 & 25.54475 & 88.96487 & Subsided area & Constant head method & $0.9450 \times 10^{-6}$ \\
\hline 3 & 25.5444 & 88.9645 & Subsided area & Constant head method & $1.1105 \times 10^{-6}$ \\
\hline 4 & 25.5524 & 88.9424 & Subsided area & Constant head method & $1.0238 \times 10^{-6}$ \\
\hline 5 & 25.5569 & 88.9476 & Subsided area & Constant head method & $0.9963 \times 10^{-6}$ \\
\hline 6 & 25.5451 & 88.9660 & Virgin area & Constant head method & $1.9839 \times 10^{-6}$ \\
\hline 7 & 25.5426 & 88.9533 & Virgin area & Constant head method & $1.9066 \times 10^{-6}$ \\
\hline 8 & 25.5427 & 88.96192 & Virgin area & Constant head method & $1.8439 \times 10^{-6}$ \\
\hline 9 & 25.5515 & 88.9412 & Virgin area & Constant head method & $1.9671 \times 10^{-6}$ \\
\hline 10 & 25.5435 & 88.9530 & Virgin area & Constant head method & $1.8302 \times 10^{-6}$ \\
\hline
\end{tabular}

its own weight. The broken ore is removed from below, and as the caved mass moves downward, it is further broken by pressure and attrition. This research physically investigated the subsidence in field through traverse method. As to this method, firstly the total subsided area marked in different direction and following directions such as NS, EW, NE-SW and NW-SE, the depth of subsidence measured from the starting point/edge of subsided area to the center of subsided area which shows that maximum subsidence of the center of subsided area is about $1 \mathrm{~m}$ which is gradually decreased toward the landward area and consequently forms a well-developed trough-like structure (Fig. 4i). The nature and shape of subsidence in field are almost trough shape over the whole mined area. Moreover, these results compared with NCB, numerical and empirically predicted subsidence model by Quamruzzaman et al. (2009), Mamun (2011), Hasan (2011), Howladar and Hasan (2014) in the area. The comparison shows the field investigated subsidence pattern and maximum depth of subsidence (Fig. 4ii) are well matched to each other. However, the development of subsidence trough above multi-slice longwall face may play a significant role to generate the fracture plane and opening of the preexisting weakness planes between the mining horizon and the surface. In this case, it can be implied that this fracture planes would be well enough to intercept surface water body and forming a direct flow path between the surface and the mining horizon consequently affects the mining as well as natural environment as a whole.

\subsection{Subsidence impacts on the land settlement with soil permeability}

The land settlement of the study area is prevailed by plain land topography (Fig. 5a, b) lies on the high Barind Tract region where the land use is dominated by agriculture. The most of the lands around the mining area are cultivated in natural way where crops are harvested in two to three times per year. The soils of the land consist of high acidity at the surface besides low acidity at depth with an excellent range of permeability which is good for water drainage characteristics (EIA 2006). Thus, the overall land settlement (Fig. 5a, b) and permeability of the soil are good for cultivation which was the common features before the mining operation, and on the other hand, the total mine out area has already been subsided and consequently changed total land settlement and crops production after the mining operation (Fig. 5c, d). From these scenarios, the present research conducted a number of field investigations and collected different data and soil samples for laboratory analysis. The investigated field data show that more than 1 sq. km land area affected by mine subsidence and in future it would be about 2.2 sq. $\mathrm{km}$ or more. The laboratory analysis of surface soil permeability shows that the permeability in the virgin land is slightly higher than the subsided area (Table 1) which reflects that the soil or overburden materials in the subsided area has compacted more and decreased its permeability characteristics which might be the direct impact of subsidence in the study area. Consequently, the total subsided area has water logged permanently and lost its crops production ability. Moreover, the similar explanation on such issue has been depicted by many researchers earlier which are mining subsidence and affects the surface land uses, crop production and grazing (Steve et al. 2002); the surface land settlement affected by ground movement is greater than the area worked in the seam (Bell et al. 2000; Hartman 1992a, b); subsidence-caused damage to surface land use is generally characterized by either a diminishment or loss of use or productivity (TEC 2007) and so many. From these discussions and also considering the present and future mining operations, this research implies that the subsidence and its associated impacts on land settlements are inherent and contemporaneous to each other which would be more 
Table 2 Monthly average water level data of two representatives deep observation well (DOB): (a) Well-11 and (b) Well-13

\begin{tabular}{|c|c|c|c|c|c|c|c|}
\hline Time & Water level (m) & Time & Water level (m) & Time & Water level (m) & Time & Water level (m) \\
\hline \multicolumn{8}{|c|}{ (a) $D O B$ Well-11 } \\
\hline Jan-01 & -5.624 & Apr-05 & -16.248 & Jul-07 & -16.934 & Oct-09 & -15.025 \\
\hline Feb-01 & -13.009 & May-05 & -15.798 & Aug-07 & -15.230 & Nov-09 & -14.535 \\
\hline Mar-01 & -11.372 & Jun-05 & -15.232 & Sep-07 & -14.830 & Dec-09 & -14.360 \\
\hline Apr-01 & -9.242 & Jul-05 & -13.434 & Oct-07 & -14.975 & Jan-10 & -14.285 \\
\hline May-01 & -9.326 & Aug-05 & -13.172 & Nov-07 & -9.534 & Feb-10 & -14.674 \\
\hline Jun-01 & -20.606 & Sep-05 & -11.740 & Dec-07 & -9.262 & Mar-10 & -14.780 \\
\hline Jul-01 & -19.592 & Oct-05 & -9.978 & Jan-08 & -9.777 & Apr-10 & -15.795 \\
\hline Aug-01 & -19.220 & Nov-05 & -11.418 & Feb-08 & -10.067 & May-10 & -15.514 \\
\hline Sep-01 & -17.632 & Dec-05 & -11.055 & Mar-08 & -10.597 & Jun-10 & -14.635 \\
\hline Oct-01 & -15.392 & Jan-06 & -12.515 & Apr-08 & -10.857 & Jul-10 & -14.424 \\
\hline Nov-01 & -14.192 & Feb-06 & -15.15 & May-08 & -11.260 & Aug-10 & -14.058 \\
\hline Dec-01 & -8.514 & Mar-06 & -16.975 & Jun-08 & -9.621 & Sep-10 & -14.455 \\
\hline Jan-03 & -11.512 & Apr-06 & -17.453 & Jul-08 & -7.925 & Oct-10 & -12.980 \\
\hline Feb-03 & -12.917 & Мay-06 & -17.418 & Aug-08 & -16.970 & Nov-10 & -12.732 \\
\hline Mar-03 & -14.817 & Jun-06 & -17.782 & Sep-08 & -16.382 & Dec-10 & -12.670 \\
\hline Apr-03 & -14.297 & Jul-06 & -17.238 & Oct-08 & -15.968 & Jan-11 & -12.450 \\
\hline May-03 & -13.920 & Aug-06 & -16.804 & Nov-08 & -15.590 & Feb-11 & -13.180 \\
\hline Jun-03 & -13.082 & Sep-06 & -16.532 & Dec-08 & -15.564 & Mar-11 & -13.725 \\
\hline Jul-03 & -10.988 & Oct-06 & -15.808 & Jan-09 & -15.635 & Apr-11 & -13.988 \\
\hline Aug-03 & -8.707 & Nov-06 & -15.500 & Feb-09 & -16.532 & Мay-11 & -14.032 \\
\hline Sep-03 & -9.735 & Dec-06 & -15.174 & Mar-09 & -17.332 & Jun-11 & -13.650 \\
\hline Oct-03 & -10.388 & Jan-07 & -14.96 & Apr-09 & -17.532 & Jul-11 & -9.500 \\
\hline Nov-03 & -9.974 & Feb-07 & -15.724 & May-09 & -17.532 & Aug-11 & -11.132 \\
\hline Dec-03 & -9.047 & Mar-07 & -16.418 & Jun-09 & -17.010 & Sep-11 & -10.632 \\
\hline Jan-05 & -13.050 & Apr-07 & -16.938 & Jul-09 & -16.905 & Oct-11 & -11.165 \\
\hline Feb-05 & -15.258 & May-07 & -17.332 & Aug-09 & -16.125 & Nov-11 & -10.620 \\
\hline Mar-05 & -16.187 & Jun-07 & -16.662 & Sep-09 & -15.455 & Dec-11 & -10.190 \\
\hline \multicolumn{8}{|c|}{ (b) $\mathrm{DOB}$ Well-13 } \\
\hline Jan-01 & 26.560 & Apr-05 & 20.844 & Jul-07 & 21.730 & Oct-09 & 22.258 \\
\hline Feb-01 & 23.710 & May-05 & 21.400 & Aug-07 & 22.556 & Nov-09 & 22.800 \\
\hline Mar-01 & 22.250 & Jun-05 & 22.345 & Sep-07 & 23.312 & Dec-09 & 23.065 \\
\hline Apr-01 & 21.560 & Jul-05 & 23.234 & Oct-07 & 23.902 & Jan-10 & 23.076 \\
\hline May-01 & 21.660 & Aug-05 & 24.706 & Nov-07 & 23.132 & Feb-10 & 22.950 \\
\hline Jun-01 & 22.463 & Sep-05 & 26.332 & Dec-07 & 23.873 & Mar-10 & 22.824 \\
\hline Jul-01 & 23.205 & Oct-05 & 26.248 & Jan-08 & 23.044 & Apr-10 & 22.368 \\
\hline Aug-01 & 23.270 & Nov-05 & 27.232 & Feb-08 & 22.573 & May-10 & 19.722 \\
\hline Sep-01 & 24.080 & Dec-05 & 26.540 & Mar-08 & 21.636 & Jun-10 & 20.110 \\
\hline Oct-01 & 26.228 & Jan-06 & 26.033 & Apr-08 & 20.763 & Jul-10 & 21.690 \\
\hline Nov-01 & 27.224 & Feb-06 & 23.800 & May-08 & 20.382 & Aug-10 & 22.940 \\
\hline Dec-01 & 27.162 & Mar-06 & 21.672 & Jun-08 & 19.962 & Sep-10 & 21.500 \\
\hline Jan-03 & 26.287 & Apr-06 & 20.540 & Jul-08 & 21.188 & Oct-10 & 22.572 \\
\hline Feb-03 & 24.022 & Мay-06 & 21.288 & Aug-08 & 22.025 & Nov-10 & 22.864 \\
\hline Mar-03 & 21.845 & Jun-06 & 21.738 & Sep-08 & 22.732 & Dec-10 & 22.695 \\
\hline Apr-03 & 22.820 & Jul-06 & 22.250 & Oct-08 & 23.778 & Jan-11 & 22.692 \\
\hline Мay-03 & 23.178 & Aug-06 & 22.540 & Nov-08 & 24.003 & Feb-11 & 20.855 \\
\hline Jun-03 & 23.780 & Sep-06 & 22.452 & Dec-08 & 23.922 & Mar-11 & 20.166 \\
\hline Jul-03 & 25.440 & Oct-06 & 23.808 & Jan-09 & 23.210 & Apr-11 & 19.395 \\
\hline
\end{tabular}


Table 2 continued

\begin{tabular}{llllllll}
\hline Time & Water level $(\mathrm{m})$ & Time & Water level $(\mathrm{m})$ & Time & Water level $(\mathrm{m})$ & Time & Water level $(\mathrm{m})$ \\
\hline Aug-03 & 27.440 & Nov-06 & 24.150 & Feb-09 & 23.000 & May-11 \\
Sep-03 & 27.628 & Dec-06 & 24.180 & Mar-09 & 21.414 & Jun-11 & 20.322 \\
Oct-03 & 27.111 & Jan-07 & 24.110 & Apr-09 & 19.632 & Jul-11 & 20.728 \\
Nov-03 & 27.902 & Feb-07 & 23.810 & May-09 & 19.458 & Aug-11 & 21.126 \\
Dec-03 & 27.047 & Mar-07 & 21.855 & Jun-09 & 19.563 & Sep-11 \\
Jan-05 & 25.464 & Apr-07 & 19.673 & Jul-09 & 20.535 & Oct-11 & 21.910 \\
Feb-05 & 21.992 & May-07 & 19.593 & Aug-09 & 21.023 & Nov-11 & 22.056 \\
Mar-05 & 21.125 & Jun-07 & 20.665 & Sep-09 & 21.300 & Dec-11 & 22.390 \\
\hline
\end{tabular}

Table 3 Comparison of the analyzed surface water quality results with WHO (2011) and EQS (1991) Bangladesh standards

\begin{tabular}{|c|c|c|c|c|c|c|c|}
\hline \multirow[t]{2}{*}{ Parameters } & \multirow[t]{2}{*}{ Unit } & \multicolumn{2}{|c|}{ WHO standard } & \multicolumn{2}{|c|}{$\begin{array}{l}\text { EQS (Bangladesh } \\
\text { standard) }\end{array}$} & \multirow{2}{*}{$\begin{array}{l}\text { Surface water from } \\
\text { subsided area } \\
\operatorname{Min}^{\mathrm{m}}-\max ^{\mathrm{m}}\end{array}$} & \multirow[t]{2}{*}{ Comments } \\
\hline & & $\begin{array}{l}\operatorname{Max}^{\mathrm{m}} \\
\text { acceptable }\end{array}$ & $\begin{array}{l}\operatorname{Max}^{\mathrm{m}} \\
\text { allowable }\end{array}$ & $\begin{array}{l}\operatorname{Max}^{\mathrm{m}} \\
\text { acceptable }\end{array}$ & $\begin{array}{l}\operatorname{Max}^{\mathrm{m}} \\
\text { allowable }\end{array}$ & & \\
\hline $\mathrm{pH}$ & - & 6.50 & 8.50 & 6.50 & 8.50 & $6.03-7.15$ & Some samples are below acceptable limit \\
\hline $\begin{array}{l}\text { Electric } \\
\text { conductance }\end{array}$ & $\begin{array}{l}\mu \mathrm{S} / \\
\mathrm{cm}\end{array}$ & 250 & 750 & 250 & - & $112-136.1$ & All samples are below standard limit \\
\hline $\mathrm{Na}^{+}$ & $\mathrm{mg} / \mathrm{l}$ & 50 & 200 & 50 & 200 & $54.1-105.6$ & All samples are within limit \\
\hline $\mathrm{K}^{+}$ & $\mathrm{mg} / \mathrm{l}$ & 150 & 250 & 100 & 150 & $7.0-10.45$ & All samples are below standard limit \\
\hline $\mathrm{Mg}^{2+}$ & $\mathrm{mg} / \mathrm{l}$ & 50 & 150 & 30 & 50 & $28-55.5$ & Most of samples are below acceptable limit \\
\hline $\mathrm{Ca}^{2+}$ & $\mathrm{mg} / \mathrm{l}$ & 75 & 200 & 75 & - & $7.1-7.2$ & All samples are below acceptable limit \\
\hline $\mathrm{Fe}^{\text {(total) }}$ & $\mathrm{mg} / \mathrm{l}$ & 0.30 & 1.0 & 0.30 & 1.0 & $0.78-0.92$ & $\begin{array}{l}\text { Some samples are below standard range and } \\
\text { some samples are within limit }\end{array}$ \\
\hline $\mathrm{Cl}^{-}$ & $\mathrm{mg} / \mathrm{l}$ & 200 & 600 & 150 & 600 & $9.8-19.6$ & All samples are below acceptable limit \\
\hline $\mathrm{SO}_{4}^{2-}$ & $\mathrm{mg} / \mathrm{l}$ & - & 250 & 400 & - & $73.1-122.3$ & All samples are below acceptable limit \\
\hline $\mathrm{HCO}_{3}{ }^{-}$ & $\mathrm{mg} / \mathrm{l}$ & 100 & 250 & 200 & 250 & $50.1-102$ & Most of samples are below acceptable limit \\
\hline $\mathrm{NO}_{3}^{-}$ & $\mathrm{mg} / \mathrm{l}$ & 45 & 100 & 45 & 100 & $12.7-21.8$ & All samples are below acceptable limit \\
\hline
\end{tabular}

by nature with time in the area. Thus, this study recommends that mining authority should take the intensive subsidence monitoring and mitigation plan which would be helpful to safe the land and environment.

\subsection{Subsidence impacts on hydrological environment}

The frequent impacts of mining subsidence on hydrological environment are to reduce the thickness of aquifer vertically; lowering the water level; reduce the permeability and porosity of aquifer bearing geologic formation; modify the hydraulic gradients, transforming the flow path and velocity; changing the natural retention features; creating the permanent water logging situation; and contaminating the surface and groundwater in the subsided area. The subsidence changes in surface slope which can adversely impact drainage along irrigated fields, canals, sewers, and natural streams (Bhattacharya and Singh 1985). Subsidence cracks increase hydraulic conductivity and interconnection of water-bearing rock units, which in turn cause increased infiltration of precipitation and surface water, decreased evapotranspiration and higher base flows in some small streams (Hobba 1993). Subsidence motivated fissuring and fracturing in overlying and neighboring strata, which influences hydrologic systems in ways that grounds change to both water quality and quantity (Steve et al. 2002). Subsidence can cause a decrease in water quality such as reduced oxygen availability, encouraging bacterial growth, smothering native plants and animals (TEC 2007). It can also increase the amount of iron oxides in the water which directly affects native plants and animals (TEC 2007). Here in this research, the impact of subsidence on hydrologic environment has been explored by conducting the field 


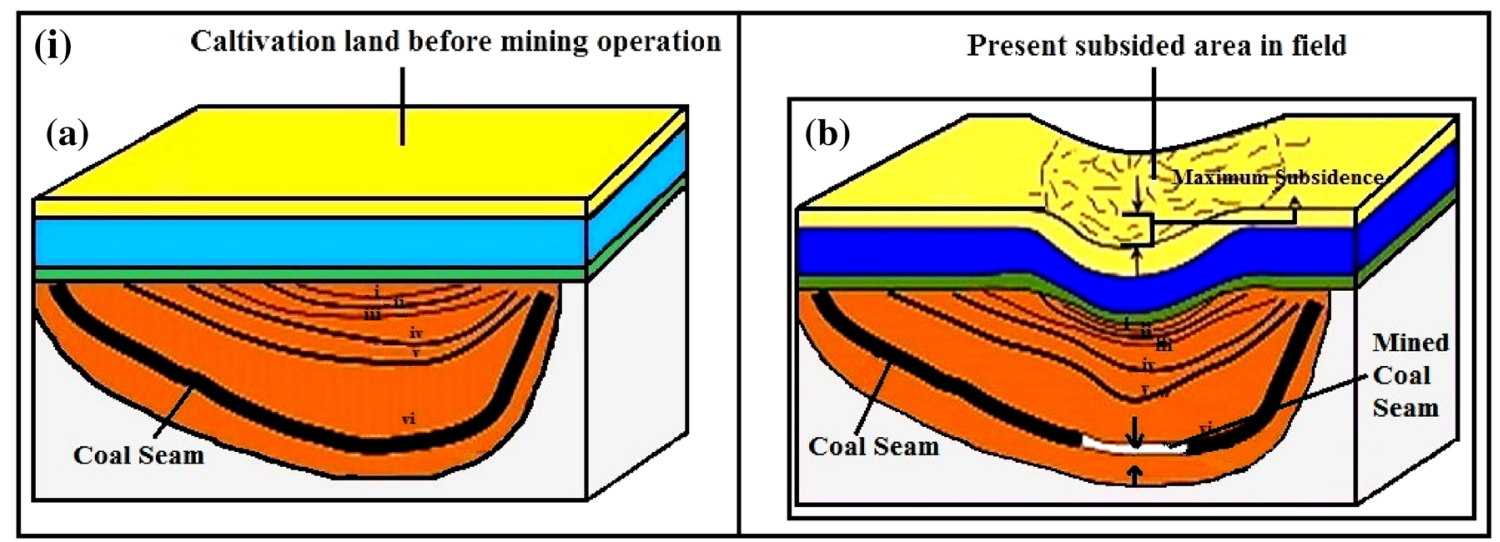

(ii)

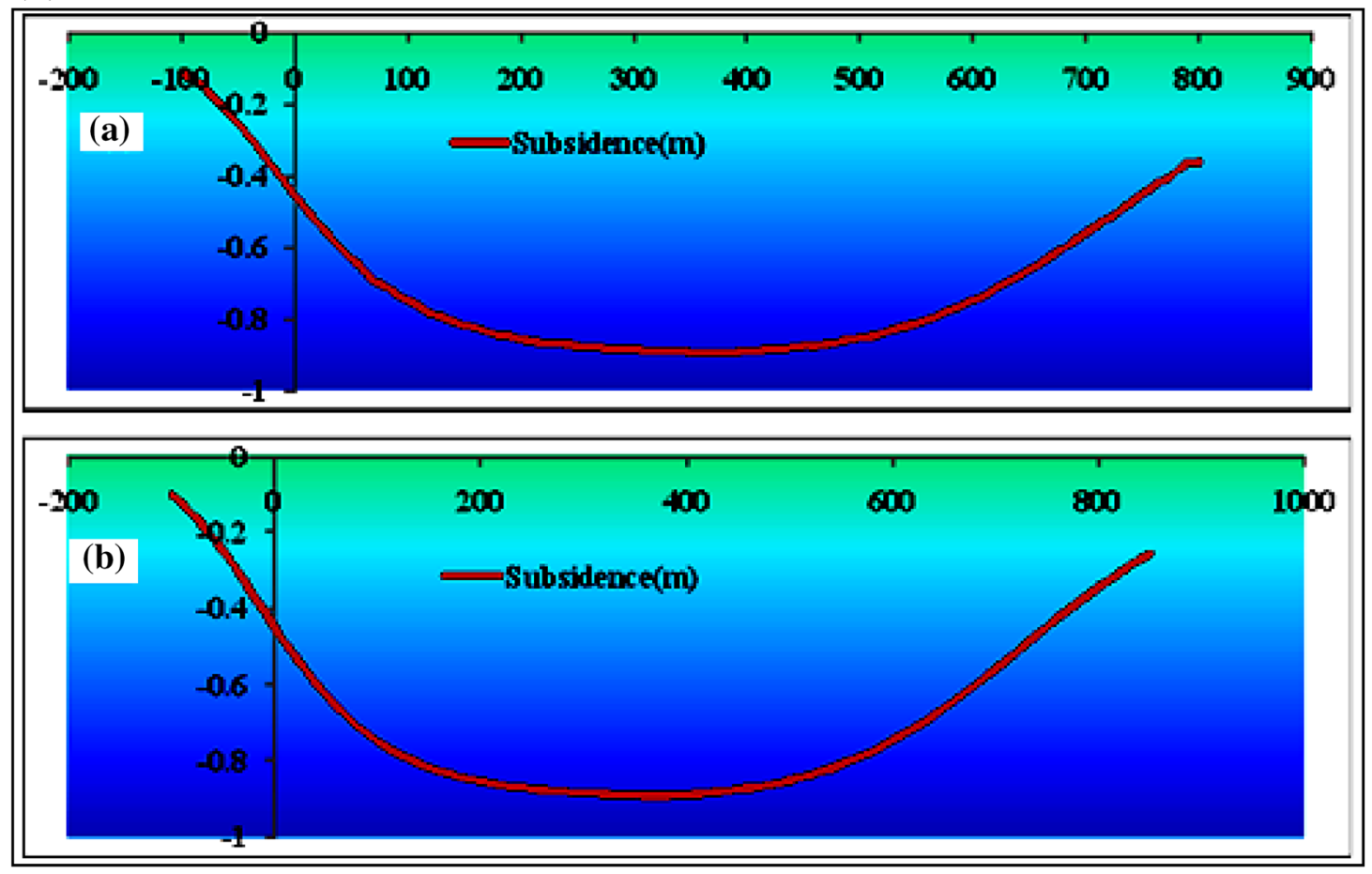

Fig. 4 Field and calculated subsidence with their comparisons $\mathbf{i} a$ predominated cultivation land and $b$ recognized pattern of subsidence in field; ii subsidence predicted under profile function method, respectively (Howladar and Hasan 2014)

investigation in the water logged area, collecting water samples from there for qualitative analysis in laboratory and also examined the characteristics of water level since 2001-2011 for some selective deep observation wells in the area. The results of the field investigation shows that the entire subsided area has been permanently water logged and forming a big lake where this water thoroughly entrapped and cannot be moved anywhere excluding rainy season causing primarily the contamination of the quality of water. The quality assessment of these water samples (Table 3 ) in the laboratory shows that water is still in normal state which also reported by Alam et al. (2011) and Howladar (2012). The examined major parameters of water such as physical parameters $\mathrm{pH}$ and $\mathrm{EC}$; chemical parameter: Cations $\mathrm{HCO}_{3}{ }^{-}, \mathrm{NO}_{3}{ }^{-}, \mathrm{SO}_{4}{ }^{2-}, \mathrm{Cl}^{-}$and anions $\mathrm{Na}^{+}, \mathrm{K}^{+}, \mathrm{Mg}^{2+}$, $\mathrm{Ca}^{2+}$ and $\mathrm{Fe}^{\text {(total) }}$ values are compared with WHO (2011) and EQS (1991) standard, which reflects that most of the parameters of water are belonging to the below standard limit which may indicate the present and future degradation of the quality of water in the area. However, the distinct classification of water for domestic, drinking, industries, livestock or irrigation purposes demand the detailed water investigations and recommendations. In the case of water level in the area, the level of water in the whole mining area lowered and changed considerably shown in Fig. 6, resulting in the interruption of local water supply chain. The 
Fig. 5 Photographs a, b and c, d shows the state of land settlement before and after subsidence, respectively. These figures are not from the same place but very close to each other, and photographs a and b are examples of predominated land pattern around the mining area
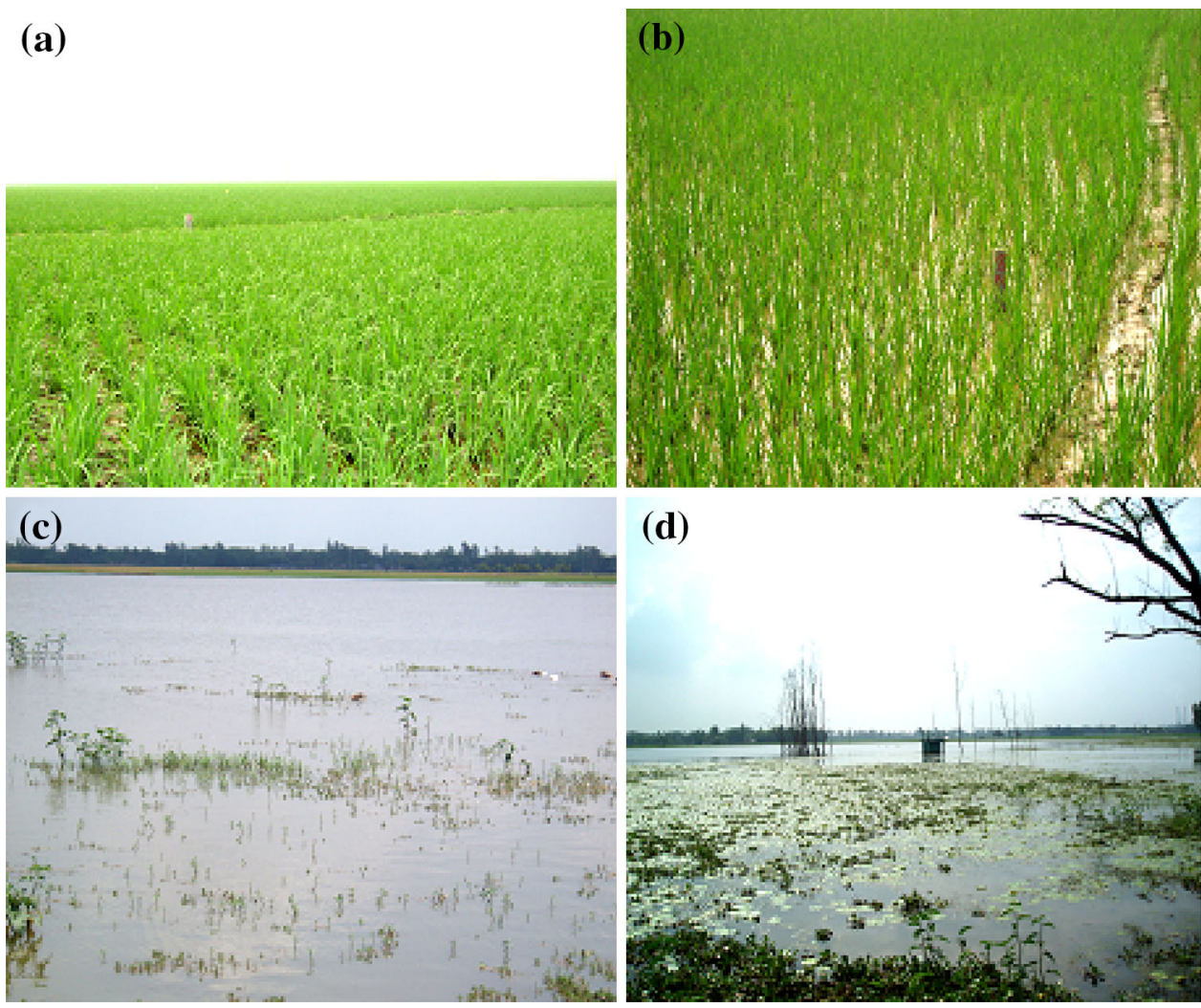

identical consequence inferred by Howladar (2012) that is the water is normally available in rainy and winter season but problematical in summer season. In fact, this characteristic is not formed by the subsidence incidence alone but mostly by the underground mine operations. Meanwhile, the Barapukuria coal basin is an asymmetrically faulted half-graben-type intracratonic basin (Bakr et al. 1996; Khan 1991). However, this major fault has affected the Basement Complex and thought to be plane of active subsidence along the southeastern extremity and marked less subsidence to the north of the basin which might have a significant role for directly infiltrated this subsided area trapped water into the aquifer as a result imbalance the water environment in the area.

\subsection{Impact of subsidence on different structures around the subsided area}

Currently, the consequences of mine subsidence upon artificial/man-made structures are well known. In principle, the longwall steps forward with the panel length causing
Fig. 6 Depletion state of water level from 2001 to 2011 in the mining area (after Howladar 2012)

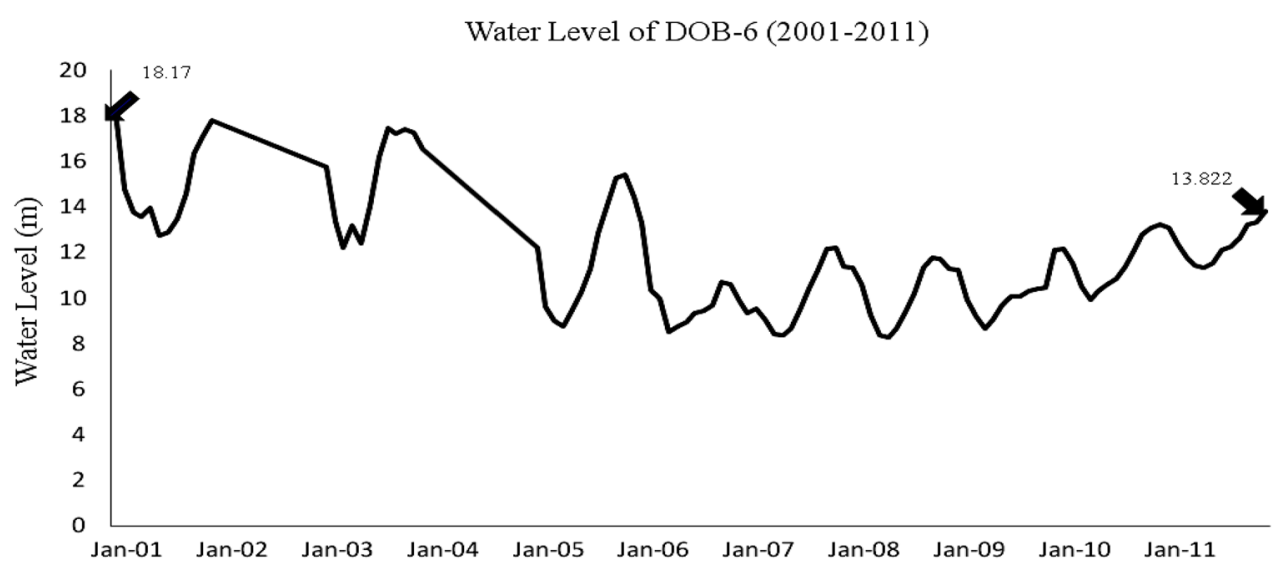


the development of the cavity. With time, the size of this cavity increased and ultimately collapsed under the burden of the overlying layers as a result of damaging the environment and human infrastructures. In principle, the major components of subsidence such as vertical displacement, horizontal displacement, slope, horizontal strain and vertical curvature are influenced the damage of environmental (SME 1992). Settlement, sinking or lowering of the surface typically manifests by vertical displacement. Horizontal displacement causes lateral movement at the surface (Karmis et al. 1983; Howladar and Hasan 2014). Horizontal strain relates to horizontal displacement, with tensile or shear forces resulting in cracking and buckling of the surface (Allgaier 1982), and is responsible for most of the damage to structures and other surface features located above mining areas (Howladar and Hasan 2014). This damage to structures can be categorized into cosmetic, functional, or structural based on the intensity of the effect of subsidence. According to Waltham (1994) and Matthew and Peter (1997), impact of subsidence on different structures can be ranking from very slight to very severe shown in Table 4. The damage due to subsidence also classified as negligible, slight, appreciable, severe and very severe by National Coal Board (Anonymous 1975; Bell et al. 2000). In this research, during the field investigation it has been observed that the mine area is surrounded by rural community and farmland where most of the structures (mud wall/brick wall or others) are suffered by cosmetic or very slight to slight damage since there is just the physical appearances of the structure are affected, such as cracking in plaster or mud/drywall (Fig. 7).

The investigation also observed that some of the wall of residential house, storage area, road and others have been experienced by structural damage, while the entire structures or foundations shifted to new place or replaced by new one. Moreover, for understanding the impacts of subsidence on structures in the fatality area, a rough statistics on various affected structures and others are shown in Table 5. In the research by Kratzsch (1983), Whittaker and Reddish (1989), Steve et al. (2002), TEC (2007) and so many pointed out on the subject of damaging the overlying mine facilities, railways and other structures by mine subsidence. However, based on the present situation around the mine area and also the nature of extraction, this study deemed that subsidence will develop progressively and continue so long as there is a progressive enlargement of the underground opening. Moreover, these conditions occurred essentially contemporaneously with mining, and therefore, the impact of subsidence on structures may be more in future; therefore, the intensive care with proper rehabilitations or compensation programs might have to be taken by the mining authority.

\subsection{Subsidence impacts on social environment around the mine}

On average, 565 people per square kilometer are living in the investigated area and approximately $0.18-0.20$ hector land is available per capita (Alam et al. 2011). The inhabitants in this area are largely engaged in farming with personal business, forestry, animal husbandry, industry, mining and also government/nongovernment services. In the case of education, the residents in the investigated area, in general most older, are illiterate; some young are attained only in the primary education; few have a secondary, higher secondary and tertiary education qualifications. Though the residents are not highly educated or familiar with modern technology, nevertheless, they are very much accommodating to each other as a result a strong social environmental chain exists in the area. However, in order to figure out the impact of subsidence on overall environment including social environment, this study conducted the community consultation/individual questionnaire survey with some selective questions to some residents around the area. The results of the survey generally demonstrate that most of the old illiterate male and female residents think that they have lost their cultivated land, residential house, play ground, storage area and others due to mine subsidence. They also think and afraid very much that probably has to leave their inherent area and shift to other in future resulting loss their social environmental chain and status. In the case of illiterate to

Table 4 Classification of the level of damage due to subsidence (after Waltham 1994; Matthew and Peter 1997)

\begin{tabular}{lll}
\hline Class & Distortion $(\mathrm{mm})$ & Typical features \\
\hline Very slight & $<30$ & Barely noticeable hair cracks in plaster \\
Slight & $30-60$ & Slight internal features, doors and windows may stick \\
Appreciable & $60-125$ & Slight external features, service pipes may fracture \\
Severe & $125-200$ & Floors slope and walls lean, door frames distorted \\
Very severe & $>200$ & Severe floor slopes and wall bulge, floor and roof beams lose bearing, needs partial or complete rebuild \\
\hline
\end{tabular}


Fig. 7 Subsidence impact on structures. For example, these representative photographs showing the effects of land subsidence on Mud wall (a and b) and Brick wall (c and d) around the mining area
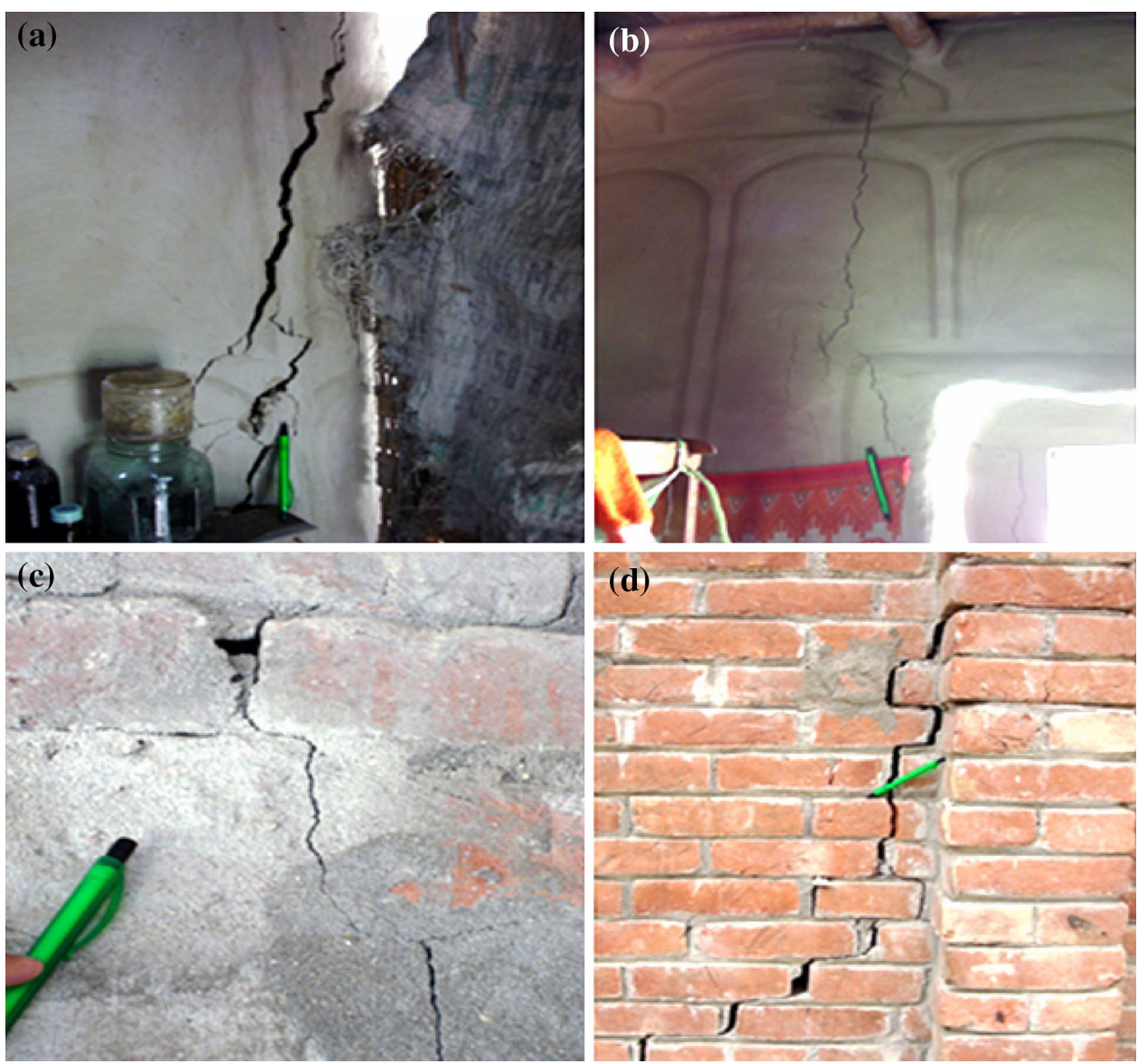

Table 5 Recognizable impact of subsidence on different events in the area (CMC 2013)

\begin{tabular}{|c|c|c|}
\hline Subsidence impacts on different events & $\begin{array}{l}\text { Total numbers/ } \\
\text { quantities }\end{array}$ & Remarks \\
\hline Total mine area & Around 3 sq. km & Plain land \\
\hline Total subsided area & 1.003 sq. $\mathrm{km}$ & 300 acre \\
\hline Projected subsided area in future & 2.173 sq. $\mathrm{km}$ & 650 acre \\
\hline Percentage of cracked building/mud wall due to subsidence & $90 \%$ & Up to 2012 \\
\hline Number of cracked roads due to subsidence & 1 & Barapukuria Khairpukur road \\
\hline $\begin{array}{l}\text { Number of damaged house, building or any infrastructures due to } \\
\text { subsidence }\end{array}$ & 1500 & Up to 2012 \\
\hline Approximate number of plants damaged & Considerable number & Not measured particularly \\
\hline Total residential house shifted & Not yet & $\begin{array}{l}\text { But will shift in future with the help of mining } \\
\text { industry }\end{array}$ \\
\hline Total number of victim family & 1500 & Up to 2012 \\
\hline Total number of victim family compensated & 1500 & $100 \%$ (up to 2012) \\
\hline
\end{tabular}

higher secondary level literate young people think that the effect of subsidence on land, infrastructure, agriculture, forestry, and water environment are much but most of them have part-time or full-time job in the mine industry. On the other hand, the literate residents have the basic idea about the impact of underground coal mine subsidence and they think that the mining industry as well as the government should take the proper rehabilitation programs in the area. Besides from the field observation, the land settlements, water resources, agricultural prospect, water and air quality 
of the area are slowly getting worst day by day. Thus, this investigation suggests for precious and immediate action plan against this incident that can be included into decision-making and show the way to reduce the social conflicts regarding the mine operation, subsidence and its impact on environment which ultimately be helpful to protected the total social-economic environmental chain and sound coal production from this mine as well as the development of other coal mines field in Bangladesh.

\subsection{Recommendations for managing mine subsidence and environment}

According to Bangladesh Power Development Board (BPDB) (2012), about $59.60 \%$ of the people in the country are getting electricity access at present. However, the available electricity in Bangladesh is 6992 MW in day and $7525 \mathrm{MW}$ in the evening, whereas forecasting current demand is $7400 \mathrm{MW}$ and $8900 \mathrm{MW}$ in day and evening, respectively. Therefore, there is a huge gap between the energy generation and the existing demand. In order to meet this demand partly, this mining industry must be continuing the extraction of coal. But by now it is observed that there is moderate to severe subsidence problem occurred around mining area. It is consistently interrupt the different components of environment. As a result, the local residents, social organizations, environment associated societies and others are much agitated and almost against to have the production of coal from this mine as well as from the other coal fields. Therefore, based on the present field and environmental condition around the subsided area, this research suggests that primarily improve the environment in the whole mining areas, secondly monitor the related environmental pollutions, and thirdly appreciate the sensitivity of the local population on environment. In addition, this research proposes the following recommendations for managing future mine subsidence and environment in the area. The recommendations are as follows:

1. Thoroughly review the existing subsidence management plan, and update it considering the contemporary field conditions and necessities around the present and projected subsided area.

2. If necessary, change the ongoing mining method partly and apply the LTCC or Coal Bed Methane (if feasible) techniques which would be more efficient to extract the coal and avoiding/reducing the subsidence.

3. Back filling mining method should be considered with the existing caving method which would provide the additional support for the stabilization of coal face upper strata, controlling ground collapse and surface subsidence.
4. A detail base map consisting the present and projected subsided area should be prearranged and published to the inhabitants belonging there which might be helpful to reduce the damage.

5. Comprehensive planning for routinely monitoring, assessing the impact of subsidence on land settlement, water, soil, different structures, plants, social environment, etc., and reporting the status to the proper authority for proper actions in the subsided area.

6. Routinely analyze and interpret the monitoring data to identify any inconsistencies and implementing the required mitigation measures and/or remedial actions immediately.

7. Consultation progressions must be undertaken with the affected landholders, local councils, local indigenous community, the general community and others which might play the significant role to have a basic knowledge on the consequences of subsidence and reduced the social environmental conflicts.

8. Designing and implementing a long-term subsidence and environmental management and monitoring plan around the total mining area.

9. Prior to commencement of the extraction of new coal face or slice, the associated environmental impact assessment and awareness programs should be undertaken which would reduce the damage in the nearby residential areas.

10. The proper rehabilitation and or compensation package must be taken and provided timely to the sufferers in the area without any harassment.

Moreover, this research believes that the proposed recommendations would be contributing to decrease the subsidence incidence, resolve the social environmental conflicts, safety of the mine to ensure the healthy production performance as well as its dependent industries ultimately which would enhance the national economy at large in the country.

\section{Conclusions}

Subsidence is an incidence which takes place due to creation of voids by extracting solids or liquids from underground. Based on various factors such as land morphology, applied mining methods, nature of extraction and rock properties, the consecutive impacts and changes may show at the surface almost concurrently with mining operation or latter. Thus, this research has been carried out to show the impact of subsidence on different components of environment under intensive field investigations, laboratory 
analysis and consultation with the community around affected area of mining industry. The results of different analyses are summarized as follows:

- From the field, it has been observed that a large areas/land a settlement about one square kilometer $\left(1^{2} \mathrm{~km}\right)$ has been subsided with a depth at the center of subsidence is about $1 \mathrm{~m}$. However, the depth of subsidence decreased gradually from center to edge, successively formed a trough subsidence structure which is supported by the previously empirically predicted intensity and pattern of subsidence in the area.

- The detectable impact of subsidence on different structures such as mud wall, brick wall of house, road, yard, land and others are deformed very slight to slight and few cases severe which would be more with time beings, while the coal extraction will be continued from one slice to other slice successively.

- In case of water environments, this investigation recognized that the whole trough area likes a big water reservoir where the water bodies are thoroughly stagnant and cannot move from this area to others apart from rainy season may follow the degradation of water quality. The water quality analysis of this area shows that the major cations and anions excluding the physical parameter $\mathrm{pH}$ values are slightly below the standard limit suggested by WHO (2011) and EQS (1991).

- The water level data analysis reveals that the water level lowered considerably with respect to its previous state. These scenarios also directly or indirectly supported by the surface soil permeability analysis results as the permeable properties reduced which might be responsible to disrupt the natural water recharge properties as a result lowering the groundwater level in the subsided area.

- The community consultations around the mines reflect a most emotional concern regarding the disordering of the social environmental chain in the community. In fact, the most of people around the area deemed that they have to lost their inherited land and social status in future. Moreover, these scenarios would be persistent for long time even after the completion of mining operation which might not be well for local communal environment and mining industry. Ultimately, it might affect the future planning and development of other coal fields in Bangladesh.

Thus, the research recommends a sustainable and comprehensive management plan for subsidence, its implementation, proper monitoring and time to time improvement based on necessities.
Acknowledgements Firstly, Dr. Howladar is all thankful to Professor Dr. Bin Chen, Editor-in-Chief for his kind cooperation regarding the encouraging review processes, advice and publication of the research. Secondly, He is cordially thankful to Dr. C. Atilla Ozturk, Associate professor, Istanbul Technical University, Turkey and other anonymous reviewers for their critical evaluation and final suggestion to publish this research. Author is also greatly thankful to Barapukuria Coal Mine Authority for providing necessary data and support for this research. Finally, the author is highly grateful to the Ministry of Science and Technology, Bangladesh, for financial support to this research project.

\section{References}

Agricola G (1950) 1556, De re metallica. In: Hoover H, Hoover LH (eds) Dover Publications, Switzerland, p 378

Alam M (1972) Tectonic classification of Bengal basin. Geol Soc Am Bull 83:519-522

Alam JB, Ahmed AAM, Khan MJH, Ahmed B (2011) Evaluation of possible environmental impacts for Barapukuria thermal power plant and coal mine. J Soil Sci Environ Manag 2(5):126-131

Allgaier FK (1982) Surface subsidence over longwall panels in the western U.S. In: Proceedings of state of the art of ground control in longwall mining and mining subsidence, SME-AIME, pp 199-210

Anonymous (1975) Subsidence engineer's handbook. National Coal Board, London

Bakr MA, Rahman QMA, Islam MM, Islam MK, Uddin MN, Resan SA, Haider MJ, Islam MS, Ali MW, Choudhury MEA, Mannan KM, Anam ANMH (1996) Geology and coal deposits of Barapukuria Basin, Dinajpur District, Bangladesh. Records of geological survey of Bangladesh, vol 8, pt 1

Bell FG, Stacey TR, Genske DD (2000) Mining subsidence and its effect on the environment: some differing examples. Environ Geol 40(1-2):35-52

Bhattacharya S, Singh MM (1985) Development of subsidence damage criteria, engineers international Inc., Prepared for U.S. Dept. of the Interior, Office of Surface Mining, Contract J51120129

Bickerstaff K, Walker G (2001) Public understandings of air pollution: the localization of environmental risk. Glob Environ Change 11(2):133-145

BPDB (Bangladesh Power Development Board) (2012) Annual report of Bangladesh Power Development Board. Unpublished report

Burland JB, Wroth CP (1975) Allowable and differential settlement of structures including damage and soil structure interaction. In: Settlement of Structures, Proceedings of the Conference of the British Geotechnical Society, Cambridge. Pentech Press, London, pp 611-654

CMC (1993, 1994, 1999) Preliminary geology and exploration report of Barapukuria Coal Mine, Bangladesh. Unpublished report

CMC (2013) Daily report of Barapukuria Coal Mine, Bangladesh. Unpublished report

Chang HC, Linlin GE, Chris R (2004) Environmental impact assessment of mining subsidence by using spaceborne radar interferometry. In: 3rd FIG regional conference Jakarta, Indonesia, October 3-7, p 13

Dong XL, Liu DM (2005) Environment Pollution during coal development and control measures. Coal Sci Technol 33(5):67-71

EIA (2006) Bangladesh: Phulbari coal project (Summary of environmental impact assessment), Project Number: 39933, p 132

EQS (1991) environmental quality standards guidelines for Bangladesh. Dept. of Environment, Bangladesh

Gregory CA (1982) Concise history of mining. Pergamon Press, Oxford, pp 614-619 
Hartman HL (1992a) SME mining engineering handbook. Society of mining, metallurgy and exploration, Inc. Port City Press, Baltimore

Hartman HL (1992b) Society of mining, metallurgy and exploration, Inc. In: SME mining engineering handbook. Port City Press, Baltimore

Hasan K (2011) Prediction of mine subsidence in Barapukuria Coal Mine, Dinajpur, Bangladesh, 142. Unpublished Thesis

Hashan M, Howladar MF, Jahan LN, Deb PK (2013) Ash content and its relevance with the coal grade and environment in Bangladesh. Int J Sci Eng Res 4(4):669-676

Hobba WA (1993) Effects of underground mining and mine collapse on the hydrology of selected basins in West Virginia, U.S. Geological Survey Water Supply Paper 2384, U.S. Department of the Interior

Howladar MF (2012) Coal mining impacts on water environs around the Barapukuria coal mining area, Dinajpur, Bangladesh. Environ Earth Sci 70:215-226. doi:10.1007/s12665-012-2117-x

Howladar MF, Hasan K (2014) A study on the development of subsidence due to the extraction of 1203 slice with its associated factors around Barapukuria underground coal mining industrial area, Dinajpur, Bangladesh. Environ Earth Sci 72(9):3699-3713. doi:10.1007/s12665-014-3419-y

Howladar MF, Karim M (2014) The selection of backfill materials for Barapukuria underground coal mine, Dinajpur, Bangladesh: insight from the assessments of engineering properties of some selective materials. Environ Earth Sci 73(10):6153-6165. doi:10. 1007/s12665-014-3841-1

Howladar MF, Islam R (2016) A study on physico-chemical properties and uses of coal ash of Barapukuria coal fired thermal power plant, Dinajpur for environmental sustainability. Energy Ecol Environ. doi:10.1007/s40974-016.0022-y

Howladar MF, Deb PK, Muzemder ATMSH, Ahmed M (2014) Evaluation of water resources around Barapukuria Coal Mine industrial area, Dinajpur, Bangladesh. Appl Water Sci. doi:10. 1007/s13201-014-0207-5

Howladar MF, Islam MT, Deb PK, Karim M, Mia MI et al (2015) An analysis of soil quality for environment around the Barapukuria coal fired thermal power plant, Parbatipur, Dinajpur, Bangladesh. Earth Resour 3:1-6. doi:10.12966/ne.05.01.2015

Imam B (2005) Energy resources of Bangladesh. University Grants Commission of Bangladesh, Dhaka, p 277

Islam MR, Hayashi D (2008) Geology and coal bed methane resource potential of the Gondwana Barapukuria Coal Basin, Dinajpur, Bangladesh. Int J Coal Geol 75:127-143

Islam MR, Hayashi D, Kamruzzaman ABM (2009) Finite element modeling of stress distributions and problems for multi-slice longwall mining in Bangladesh, with special reference to the Barapukuria Coal Mine. Int J Coal Geol 78:91-109

Karim MM, Howladar MF (2013) Volumetric estimation of coal resources in seam VI for require backfill Materials of Barapukuria Coal Mine, Dinajpur, Bangladesh. J Earth Sci 2(6):113-119. doi:10.11648/j. earth.20130206.11

Karim MM, Howladar MF, Shine FMM (2014) A study on the preliminary cost estimation for hydraulic backfill process in Barapukuria Coal Mine, Dinajpur, Bangladesh. J Eng Geol Hydrogeol 2(3):37-45. doi:10.12966/jegh.08.02.2014

Karmis M, Triplett T, Haycocks C, Goodman G (1983) Mining subsidence and its prediction in the appalachian coalfield. In: Proceedings of the 24th U.S. symposium on rock mechanics, pp 665-675

Khan FH (1991) Geology of Bangladesh. Willey Eastern Limited, New Delhi, pp 33-40

Khan AA, Rahman T (1992) An analysis of gravity and tectonic evaluation of north-western part of Bangladesh. Tectophysics 206:351-364
Khan AA, Agarwal BNP (1993) Crustal structure of western Bangladesh from gravity data. Tectonophysics 219:341-353

Khan AA, Chouhan RKS (1996) The crustal dynamics and the tectonic trends in the Bengal basin. J Geodyn 22:267-286

König HJ, Schuler J, Suarma U, McNeill D, Imbernon J, Damayanti F, Dalimunthe SA, Uthes S, Sartohadi J, Helming K, Morris J (2010) Assessing the impact of land use policy on urban-rural sustainability using the FoPIA approach in Yogyakarta, Indonesia. Sustainability 2:1991-2009

Kratzsch H (1983) Mining subsidence engineering (Fleming RFS, Trans). Springer, New York, pp 1-40

Mamun A (2011) Mine induced subsidence assessment of MoupukurArea, Barapukuria. Unpublished M.Sc. Thesis

Matthew RB, Peter D (1997) Environmental geology, geology and the human environment. Wiley, England, p 489

Muller M (2009) It is not only coal mining: coal bed methane and underground coal gasification potential in Bangladesh. A brief independent technical review written for mines and communities website, $\mathrm{p} 38$

Park DW (1987) Effect of mine subsidence on ground water hydrology, 8. Society of Mining Engineers, AIME, pp 87-98

Polshin DE, Tokar RA (1957) Maximum allowable non-uniform settlement of structures. In: Proceedings of the 4th international conference on soil mechanics and foundation engineering, vol 1. London, pp 402-406

Quamruzzaman C, Howladar MF, Golam AK, Ahmed M (2009) Surface subsidence prediction in Barapukuria Coal Mine, Dinajpur, Bangladesh. Int J Earth Sci Eng 2:55-62

Shi XM, Han SS, An PF, Guo XG (2010) The environment vulnerability assessment of typical resources based urban in Mid-West China. Areal Res Dev 29(6):63-68

Singh MM (1992) Mine subsidence, SME handbook. SME, pp 938-971

Skempton AW, MacDonald DH (1956) Allowable settlement of buildings. Proc Inst Civil Eng 5(3):727-768

Soliman M (1998) Environmental hydrogeology. CRC Press LLC, Boca Raton, pp 81-101

SRDI (1999) Soil Resource Development Institute Dinajpur. Unpublished

Steve BMS, James R, Kuipers PE (2002) Technical report on underground hard-rock mining: subsidence and hydrologic environmental impacts, 50. Center for Science in Public Participation, Bozeman, p 72

Total Environment Centre (TEC) (2007) Impacts of longwall coal mining on the environment in New South Wales. Environmental Defender's Office Ltd, Sydney South 1235, pp 1-35

Uddin MK (2003) Chemistry of drainage water from the Barapukuria Coal Mine, Bangladesh: it's suitability for utilization, 99. Unpublished M.Sc. Thesis

Uddin MN, Islam MS (1992) Gondwana basins and their coal resources in Bangladesh, Geology in South Asia-1. In: Proceedings of the first south Asian geological congress, Pakistan, pp 224-230

Waltham AC (1994) Foundations of engineering geology. Blackie, Glasgow, p 63

Wardell A (1991) Techno-economic feasibility study, Barapukuria coal project, Dinajpur District, Bangladesh, vol 1 \& 2 . Unpublished

Whittaker BN, Reddish DJ (1989) Subsidence occurrence, prediction and control. Elsevier, Amsterdam, p 528

WHO (2011) Guidelines for drinking water quality, 4th edn. Organization of World Health Organization, Geneva

Zaher MA, Rahman A (1980) Prospects and investigations for mineral in northern part of Bangladesh, petroleum and mineral resource of Bangladesh, seminar and exhibition, October 08-12, Dhaka 